\title{
The Structure Formation and Evaluation of the Properties of Polymermatric Composites Based on Sub-Microdimensional Fillers
}

\author{
T.P. Ustinova*, L.G. Panova, Yu.A. Kadykova, N.L. Levkina \\ Engels Technological Institute (Branch), Gagarin Saratov State Technical University, \\ 17, Pl. Svobody, Engels, Saratov region, 413100, Russia \\ * Corresponding author: Tel.: +7 (8453) 5686 18.E-mail:xt.techn.sstu@yandex.ru
}

\begin{abstract}
The effect of submicrocore fillers on the processes of structure formation, structural features and operational properties of filled composites based on thermoplastic and thermo-reactive matrices was studied. It was found that the introduction of the investigated fillers creates conditions for the growth of linear macromolecules of epoxy binders, providing an increase in the deformation properties of the composite based on it. The consequence of the modification of polyamide 6 is an increase in the degree of crystallinity of the polymer, which contributes to an increase in the physico-mechanical characteristics of the modified polymer.
\end{abstract}

\section{Keywords}

Polymer matrix composites; epoxy binder; polyamide 6; submicrometer fillers; potassium polititanate; dispersed basalt; combination of components; kinetics of curing; parameters of supramolecular structure; performance properties.

(C) T.P. Ustinova, L.G. Panova, Yu.A. Kadykova, N.L. Levkina, 2018

Polymer-matrix composites based on dispersedfibrous fillers refer to promising materials widely used in various industries. Currently, the main trend is the development of composite materials for specific applications with a given set of operational properties [1-3], as well as alternative science-intensive technologies for their production [4-7].

In recent years functional fillers, including nanoand submicro-dimensional [8,9] ones have been developed for the directed regulation of the structure of polymer matrix composite materials (PMCM) and giving new functional properties to them. In this regard, it becomes urgent to study the features of creating polymer matrix composites based on ingredients of the new generation.

To assess the effect of the above fillers on the structure formation processes and the operational properties of PMCM, both traditional methods of combining the components and methods of polycondensation and polymerization filling were used.

The obtained experimental data (Fig. 1) indicate that the active influence of submicron-size fillers potassium tetrathionate (PT) and dispersed basalt is manifested when they are introduced into the thermoset epoxy binder, which is confirmed by the conducted kinetic studies. And this influence is determined by the chemical nature of the filler (Table 1).

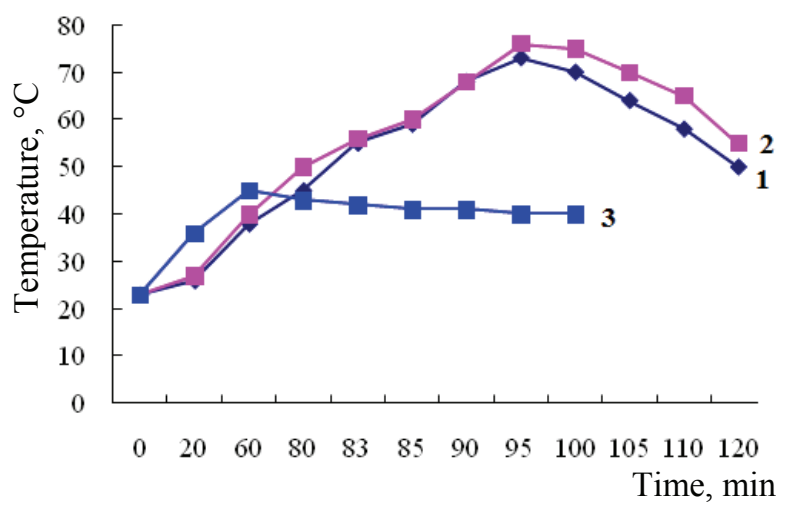

Fig. 1. Kinetic parameters of curing epoxy compositions, hardened 15 parts by weight Polyethylenepolyamines: $1-70$ epoxy-20+30trichloroethylphosphate + +1 potassium tetrathionate;

$2-70$ epoxy-20+30trichloroethylphosphate + +5 potassium tetrathionate;

$3-70$ epoxy-20+30trichloroethylphosphate + +50 potassium tetrathionate 
Kinetics of curing epoxy compositions

\begin{tabular}{|c|c|c|c|}
\hline $\begin{array}{c}\text { Composition of the material, cured } 15 \text { parts by weight } \\
\text { of Polyethylenepolyamines }\end{array}$ & $\begin{array}{l}\text { Gelation time, } \\
\tau_{\text {gel }}, \min \end{array}$ & $\begin{array}{l}\text { Curing } \\
\text { time, } \tau_{\text {cur }}, \min \end{array}$ & $\begin{array}{c}\text { Max. curing } \\
\text { temperature, } \\
T_{\max },{ }^{\circ} \mathrm{C}\end{array}$ \\
\hline 70epoxy-20 +30trichloroethylphosphate & 36 & 50 & 130 \\
\hline 70epoxy-20 +30 trichloroethylphosphate +1 potassium tetrathionate & 26 & 95 & 73 \\
\hline 70 epoxy-20 +30 trichloroethylphosphate +5 potassium tetrathionate & 27 & 95 & 76 \\
\hline 70 epoxy-20 +30 trichloroethylphosphate +50 potassium tetrathionate & 25 & 60 & 45 \\
\hline 70 epoxy-20 +30 trichloroethylphosphate +1 basalt & 33 & 70 & 120 \\
\hline 770 epoxy-20 +30 trichloroethylphosphate +5 basalt & 54 & 70 & 110 \\
\hline 70epoxy-20 +30 trichloroethylphosphate +50 basalt & 44 & 82 & 85 \\
\hline
\end{tabular}

Properties of epoxy compositions cured with Polyethylenepolyamines

\begin{tabular}{|c|c|c|c|c|c|}
\hline Composition, pbw & $\begin{array}{c}\text { Breaking } \\
\text { bending } \\
\text { stress, MPa }\end{array}$ & $\begin{array}{c}\text { Impact } \\
\text { strength, } \\
\mathrm{kJ} / \mathrm{m}^{2}\end{array}$ & $\begin{array}{c}\text { Brinell } \\
\text { hardness, } \\
\mathrm{MPa}\end{array}$ & $\begin{array}{c}\text { Wear } \\
\text { by weight } \\
\text { in friction, } g\end{array}$ & $\begin{array}{c}\text { Oxygen } \\
\text { index, } \\
\% \text { vol. }\end{array}$ \\
\hline 70epoxy-20 lb & 17 & 3 & 110 & 0.0048 & 19 \\
\hline 70 epoxy-20 + 30trichloroethylphosphate & 50 & 7 & 77 & 0.0115 & 24 \\
\hline $\begin{array}{l}\text { 70epoxy- } 20+30 \text { trichloroethylphosphate }+ \\
+1 \text { potassium tetrathionate }\end{array}$ & 35 & 10 & 105 & 0.0002 & 28 \\
\hline
\end{tabular}

Filling the epoxy matrix with basalt leads to an increase in the viability of the formulations, since the gelation time increases from 36 (without filler) to 44-54 min in the composition. At the same time, the curing time is increased from 70 minutes (without filler) to 82 minutes; the maximum curing temperature is significantly reduced from $130^{\circ} \mathrm{C}$ to $110-85^{\circ} \mathrm{C}$, which, on the whole, improves the technological properties of the resulting composition.

The introduction of potassium tetrathitanate in the epoxy matrix modified with trichloroethylphosphate reduces the gelation time from 36 to $27-25 \mathrm{~min}$ and a maximum curing temperature from 130 to 73,76 and $45^{\circ} \mathrm{C}$, respectively. However, the curing time is increased from 50 to $60-95 \mathrm{~min}$, which may indicate an increase in the possibility of forming a linear chain of the macromolecule. A consequence of this is an increase in the physical-mechanical properties of the resulting composites.

The study of the influence of small additives of potassium tetrathionate on the physical-mechanical properties of epoxide-based composites modified with trichloroethylphosphate (Table 2) showed an increase in resistance to bending, impact, increase in hardness and decrease in frictional wear. At the same time, an additional increase in the oxygen index (from 24 to $28 \%$ vol.) makes it possible to classify the resulting composite as a non-combustible material.

The analysis of the physical-mechanical properties of epoxide compositions filled with basalt also confirms the effectiveness of introducing a submicrometer filler (Table 3). In this case, the addition of 50 parts by weight of basalt provides an increase in impact strength (by $60 \%$ ), material hardness (by $94 \%$ ), breaking bending stress (by $171 \%$ ) and heat resistance of PCM (by $66-92{ }^{\circ} \mathrm{C}$ ) compared to an unfilled epoxy matrix.

The introduction of submicro-fillers in the thermoplastic matrix is Effective, it allows for the correction of the properties of the produced PMCM.

The modification of the polyamide matrix by introducing the potassium tetrathionate at the stage of polymer synthesis or by combining it with polyamide6 granulate confirms the significant effect of the modifier on the structure formation processes that occur during matrix formation (Fig. 2).

As it follows from the IRS data, regardless of the method of introducing the filler, the intensity of the absorption bands characteristic of amide, amino and carboxy groups (3065-3300, 1640 and $1545 \mathrm{~cm}^{-1}$, 
$1030-900 \mathrm{~cm}^{-1}$ ) is observed. Their shift in the region of lower frequencies, which indicate the occurrence of interfacial, adhesive interaction in modified polyamide- 6 , ensuring the growth of ordered regions, leads to an increase in the degree of crystallinity of the polymer (Table 4).

The influence of the filler on the formation of the structure of the polymer matrix results in a change in physical-mechanical properties of polyamide- 6 filled with potassium tetrathitanate. As can be seen from Table 5 there is a tendency to increase its physicalmechanical properties. Thus, for a composite with a $10 \%$ potassium tetrathionate content, the breaking stress increases by $50 \%$ during compression, the material hardness increases by $36 \%$, and its heat resistance increases by $23{ }^{\circ} \mathrm{C}$.

In the traditional combination of potassium tetrathitanate with the polyamide- 6 granulate, it was technologically possible to introduce filler in an amount of up to $30 \%$, which ensures the production of a composite material with enhanced properties at $10 \%$ potassium tetrathitanate content (Table 6).

A comparative analysis of the properties of polyamide- 6 filled by different methods (Fig. 3)

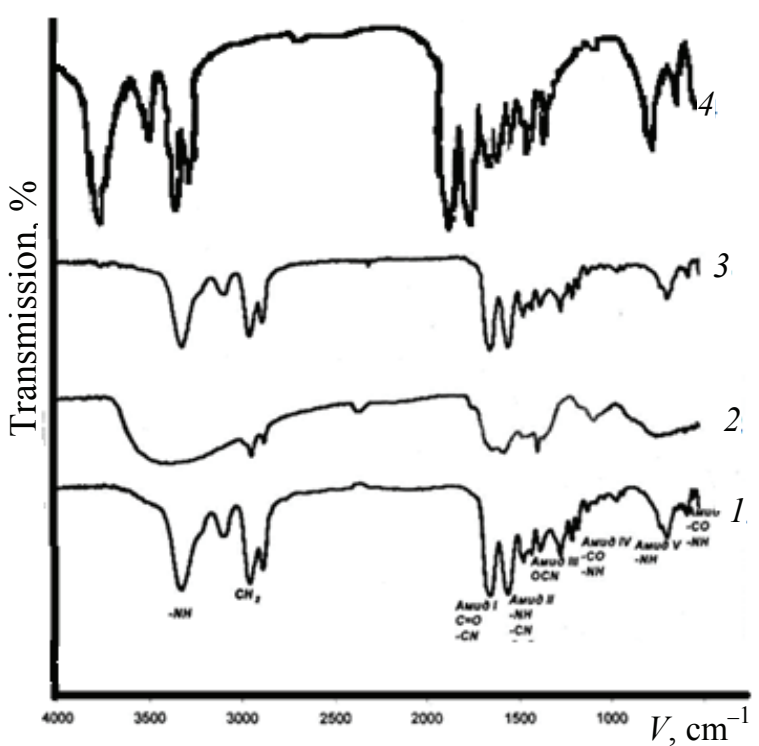

Fig. 2. IR spectra:

1 - polyamide- $6 ; 2$ - potassium tetrathionate;

3 - polyamide- 6 (granulate) $+1 \%$ potassium tetrathionate; 4 - polyamide- $6+1 \%$ potassium tetrathionate, introduced at the stage of polyamide synthesis

indicates that the introduction of potassium tetrathitanate in both cases provides an increase in the basic physical-mechanical properties of the composite.

Table 3

The effect of basalt on physical-mechanical properties of epoxide compositions modified with trichloroethylphosphate in the proportion 70 epoxy-20 pbw +15 Polyethylenepolyamines pbw + +30 trichloroethylphosphate pbw

\begin{tabular}{cccccc}
\hline Basalt, pbw & $\begin{array}{c}\text { Impact strength, } \\
\mathrm{kJ} / \mathrm{m}^{2}\end{array}$ & $\begin{array}{c}\text { Brinell hardness, } \\
\text { MPa }\end{array}$ & $\begin{array}{c}\text { Breaking bending } \\
\text { stress, MPa }\end{array}$ & $\begin{array}{c}\text { Water absorption, } \\
\%\end{array}$ & $\begin{array}{c}\text { Vicat heat resistance, } \\
{ }^{\circ} \mathrm{C}\end{array}$ \\
\hline- & 34 & 130 & 45 & 0.20 & 114 \\
1 & 37 & 134 & 50 & 0.17 & 124 \\
30 & 39 & 185 & 77 & 0.10 & 180 \\
50 & 55 & 253 & 122 & 0.07 & 206 \\
\hline
\end{tabular}

Table 4

Parameters of the supermolecular structure of the investigated composition

\begin{tabular}{lccc}
\hline \multirow{2}{*}{ Polymer } & \multicolumn{2}{c}{ Degree of crystallinity, \% } & Crystallite size, $\AA$ \\
\hline \multirow{2}{*}{ PA-6 } & by IRS & by X-ray diffraction & $\underline{42}$ \\
\multirow{2}{*}{ PA-6 modified } & $\underline{17.7}$ & $\underline{17.4}$ & - \\
& $\underline{21.4}$ & - & $\underline{28}$ \\
\hline
\end{tabular}

Note: the numerator - samples synthesized in the laboratory; the denominator - samples based on granulated polyamide- 6 . 
Physical-mechanical properties of polymerization-filled polyamide-6

\begin{tabular}{cccccc}
\hline $\begin{array}{c}\text { Filler content, } \\
\% \text { mass kl }\end{array}$ & $\begin{array}{c}\text { Density, } \\
\mathrm{kg} / \mathrm{m}^{3}\end{array}$ & $\begin{array}{c}\text { Breaking } \\
\text { bending stress, } \\
\mathrm{MPa}\end{array}$ & $\begin{array}{c}\text { Brinell } \\
\text { hardness, } \\
\mathrm{MPa}\end{array}$ & $\begin{array}{c}\text { Vicat heat } \\
\text { resistance, } \\
{ }^{\circ} \mathrm{C}\end{array}$ & $\begin{array}{c}\text { Water } \\
\text { absorption } \\
\text { for 24 } \mathrm{h}, \%\end{array}$ \\
\hline- & 1090 & 36 & 64 & 180 & 1.3 \\
10 & 1157 & 70 & 87 & 203 & 4.4 \\
20 & 1320 & 59 & 97 & 168 & 5.2 \\
30 & 1444 & 54 & 24 & 200 & 8.9 \\
40 & 1564 & 116 & 110 & 194 & 9.9 \\
\hline
\end{tabular}

Deformation-strength properties of polyamide-6 filled with potassium tetrathitanate

Table 6

\begin{tabular}{cccccc}
\hline $\begin{array}{c}\text { Filler } \\
\text { content, \% }\end{array}$ & $\begin{array}{c}\text { Ultimate tensile } \\
\text { stress, MPa }\end{array}$ & $\begin{array}{c}\text { Elastic modulus at } \\
\text { tension, \% }\end{array}$ & $\begin{array}{c}\text { Breaking bending } \\
\text { stress, MPa }\end{array}$ & $\begin{array}{c}\text { Impact strength, } \\
\mathrm{kJ} / \mathrm{m}^{2}\end{array}$ & $\begin{array}{c}\text { Brinell } \\
\text { hardness, MPa }\end{array}$ \\
\hline- & 38.5 & 36.0 & 73.5 & 19.0 & 143.0 \\
10 & 42.5 & 43.0 & 106.0 & 25.5 & 176.5 \\
20 & 41.5 & 42.0 & 105.0 & 26.0 & 154.0 \\
30 & 43.0 & 31.5 & 105.5 & 27.0 & - \\
\hline
\end{tabular}
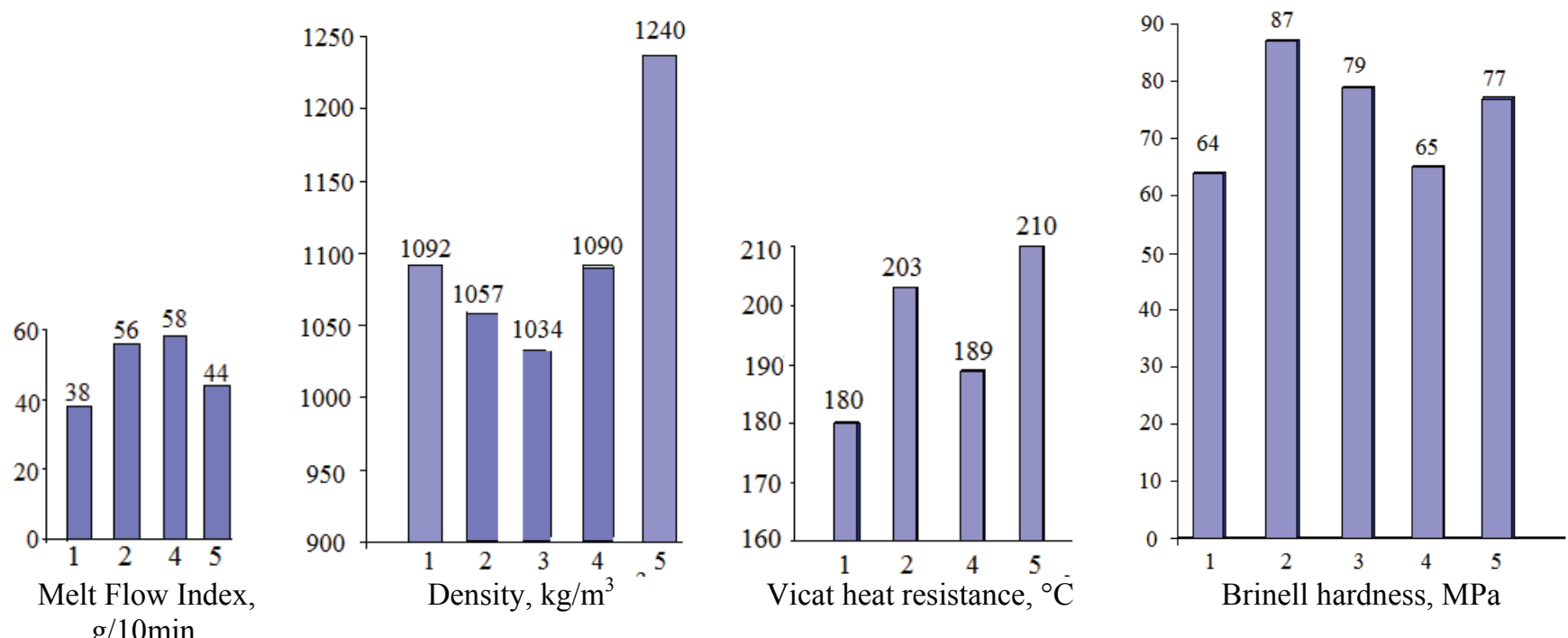

Fig. 3. Physical-mechanical properties of filled polyamide-6:

1 - polyamide- 6 without fillers; 2 - polyamide- $6+10 \%$ potassium tetrathitanate (synthesis stage);

3 - PA-6 (granulate) $+10 \%$ potassium tetrathitanate; 4 - polyamide- $6+1 \%$ potassium tetrathitanate (synthesis stage);

5 - polyamide- 6 (granulate) $+1 \%$ potassium tetrathitanate

Complex studies of the processes of structure formation in composite materials based on a polyamide matrix and a submicrosized filler - potassium tetrathitanate, the study of the effect of potassium tetrathitanate and submicro-size basalt on the kinetics of the curing process and the physical and mechanical properties of epoxy composites have made it possible to formulate the main conclusions characterizing the specific regulation of structure and performance properties PMCM: 
- Kinetic studies of the curing process of epoxy binder modified by trichloroethylphosphate in the presence of submicrometer additives (potassium tetrathitanate, dispersed basalt) both as modifiers and as fillers indicate their significant influence on process parameters. At the same time, this is manifested to a greater extent in the increase in the curing time, which creates the conditions for preferential growth of the linear chains of the macromolecule, which results in an increase in the toughness, breaking bending stresses, and the hardness of the composite, while increasing the oxygen index.

- The study of the structural features of polyamide 6 , modified at the stage of synthesis by submicron-size potassium tetrathitanate, also confirms its active influence on the formation of the polymer matrix, which results in an increase in the degree of crystallinity of the polymer and an improvement in its physical and mechanical properties.

\section{References}

1. Berlin A.A. (ed) Polimernye kompozicionnye materialy: struktura, svojstva, tehnologija [Polymer composite materials: structure, properties, technology]. SPb.: Professija, 2014, 592 p. (Rus)

2. Mihajlin Ju.A. Special'nye polimernye kompozicionnye materialy [Special polymeric composite materials]. SPb.: Nauchnye osnovy i tehnologii, 2009. 660 s. (Rus)

3. Bobryshev A.N., Erofeev V.T., Kozomazov V.N. Polimernye kompozicionnye materialy [Polymeric composite materials]. M.: Izd-vo ASV, 2013. 473 p. (Rus)

4. Enikolopjan N.S., Pshechenkov P.A., Grigorov L.N. Issledovanie struktury pripoverhnostnogo sloja polijetilena $v$ polimerizacionno napolnennom perlite [Investigation of the structure of the nearsurface layer of polyethylene in a polymerisation-filled perlite]. Doklady AN SSSR. 1983. Vol. 269, Issue 1, p. 140. (Rus)

5. Galashina N.M. Polimerizacionnoe napolnenie kak metod poluchenija novyh kompozicionnyh materialov [Polymerization filling as a method of obtaining new composite materials]. Vysokomolekuljarnye soedinenija. 1994. Vol. 36, Issue 4, p. 640. (Rus)

6. Kadykova Ju.A. Fiziko-himicheskie zakonomernosti sozdanija polimermatrichnyh kompozitov funkcional'nogo naznachenija na osnove bazal'tovyh dispersnovoloknistyh napolnitelej, uglerodnyh $i$ stekljannyh volokon: diss. ... d-ra tehn. nauk: 05.17.06 [Physicochemical regularities in the development of polymer matrix composites of functional purpose on the basis of basalt dispersed fibrous fillers, carbon and glass fibers: diss. ... dr. tech. sci.: 05.17.06]. Saratov: 2013, 308 p. (Rus)

7. Leonov D.V., Levkina N.L., Ustinova T.P. Vybor sostava i kompleksnaja ocenka svojstv poliamida-6, modificirovannogo okislennym grafitom [The choice of composition and complex assessment of the properties of polyamide- 6 modified with oxidized graphite]. Zhurnal prikladnoj himii. 2015. Vol. 88, Issue 6. pp. 957-962. (Rus)

8. Patent N 2366609 (2008). Bul. 2009. Vol. 25. (Rus)

9. Gorohovskij A.V., Palagin A.I., Panova L.G., Ustinova T.P., Burmistrov I.N., Aristov D.V. Proizvodstvo submikro-nanorazmernyh polititanatov kalija $i$ kompozicionnyh materialov na ih osnove [Production of submicron-nanosized potassium polytitanates and composite materials on their basis]. Nanotehnika. 2009, Vol. 19. pp. 38-44. (Rus) 